Supporting Information for the Paper Entitled:

\title{
Aqueous Stability and Ligand Substitution of a Layered Cu(I)/Isocyanide- Based Organometallic Network Material with a Well-Defined Channel Structure
}

\author{
Alejandra Arroyave, Milan Gembicky, Arnold L. Rheingold and Joshua S. Figueroa* \\ Department of Chemistry and Biochemistry, University of California, San Diego, 9500 Gilman \\ Drive, Mail Code 0358, La Jolla, CA 92093-0358, United States.
}

\section{Contents}

S1. ${ }^{1} \mathrm{H}$ NMR and IR Spectroscopic Data for $1,4-\left(\mathrm{CNAr}^{\mathrm{Mes} 2}\right)_{2} \mathrm{C}_{6} \mathrm{H}_{4}$ and Precursors $\ldots . . . . . . . . \mathrm{S}-2$

S2. ATR-IR Spectroscopic Data for THF- and Pyridine-Coordinated Cu- ${ }^{\mathrm{ISO}} \mathrm{CN}-4 \quad \ldots . . . . . . . \mathrm{S}-5$

S3. Details of X-ray Single-Crystal and Powder Diffraction Studies ......................................S-7

S4. TGA, Porosimetry and Contact Angle Measurements on Cu- ${ }^{\mathrm{ISO}} \mathrm{CN}-4$..................... S-11

S.5. References .............................................................................................................................. S-13 
S1. ${ }^{1} \mathrm{H}$ NMR and IR Spectroscopic Data for $1,4-\left(\mathrm{CNAr}^{\mathrm{Mes} 2}\right)_{2} \mathrm{C}_{6} \mathrm{H}_{4}$ and Precursors.

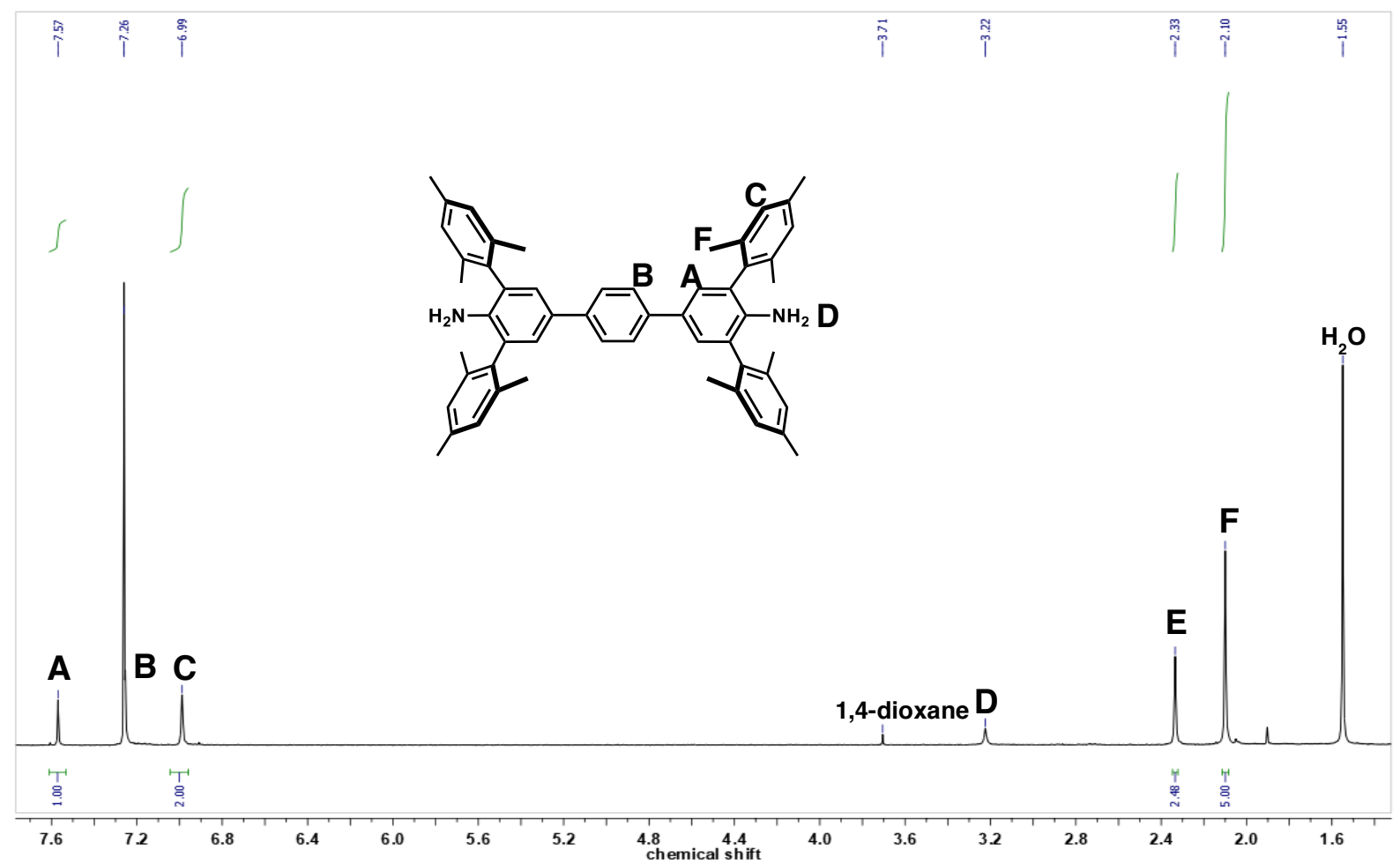

Figure S1.1. ${ }^{1} \mathrm{H}$ NMR spectrum $\left(\mathrm{CDCl}_{3}, 300 \mathrm{MHz}, 20{ }^{\circ} \mathrm{C}\right)$ of $1,4-\left(\mathrm{H}_{2} \mathrm{NAr}^{\mathrm{Mes} 2}\right)_{2} \mathrm{C}_{6} \mathrm{H}_{4}$.

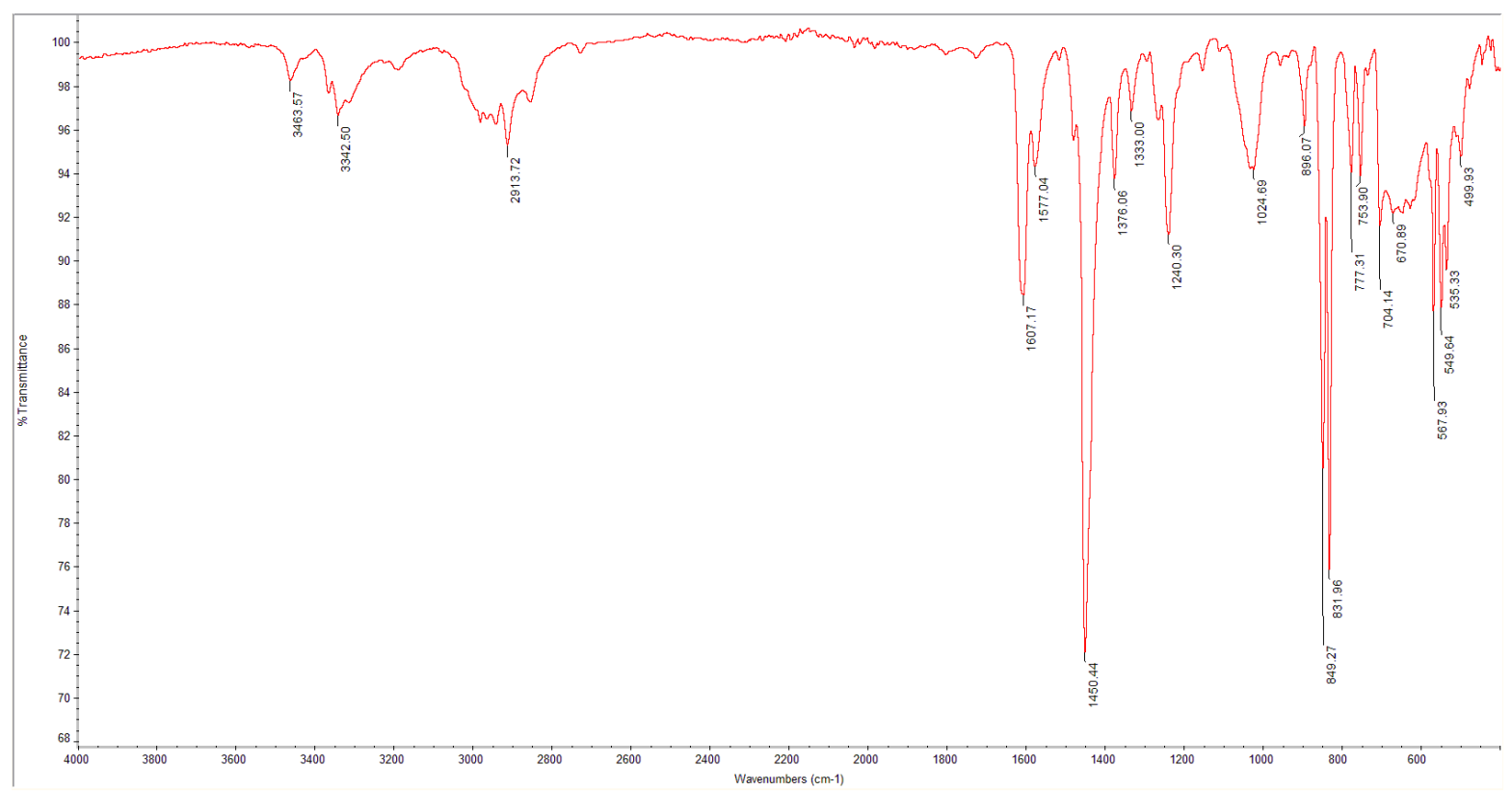

Figure S1.2. ATR-IR spectrum $\left(20^{\circ} \mathrm{C}\right)$ of $1,4-\left(\mathrm{H}_{2} \mathrm{NAr}{ }^{\mathrm{Mes} 2}\right)_{2} \mathrm{C}_{6} \mathrm{H}_{4}$. 


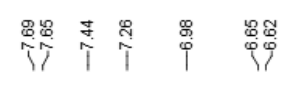

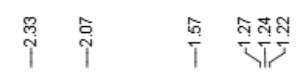

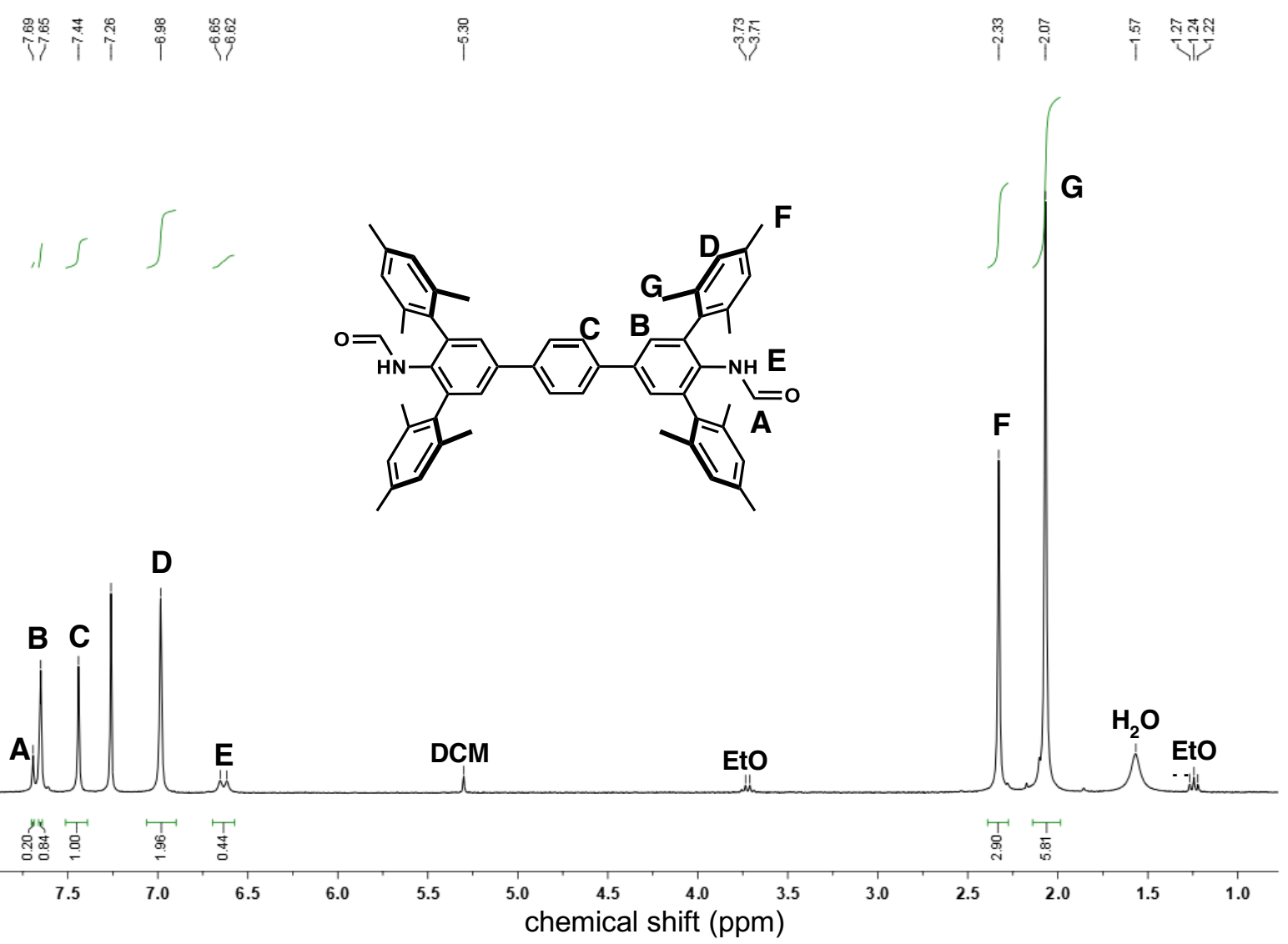

Figure S1.3. ${ }^{1} \mathrm{H}$ NMR spectrum $\left(\mathrm{CDCl}_{3}, 300 \mathrm{MHz}, 20{ }^{\circ} \mathrm{C}\right)$ of $1,4-\left(\mathrm{HC}(\mathrm{O}) \mathrm{N}(\mathrm{H}) \mathrm{Ar}^{\mathrm{Mes} 2}\right)_{2} \mathrm{C}_{6} \mathrm{H}_{4}$.

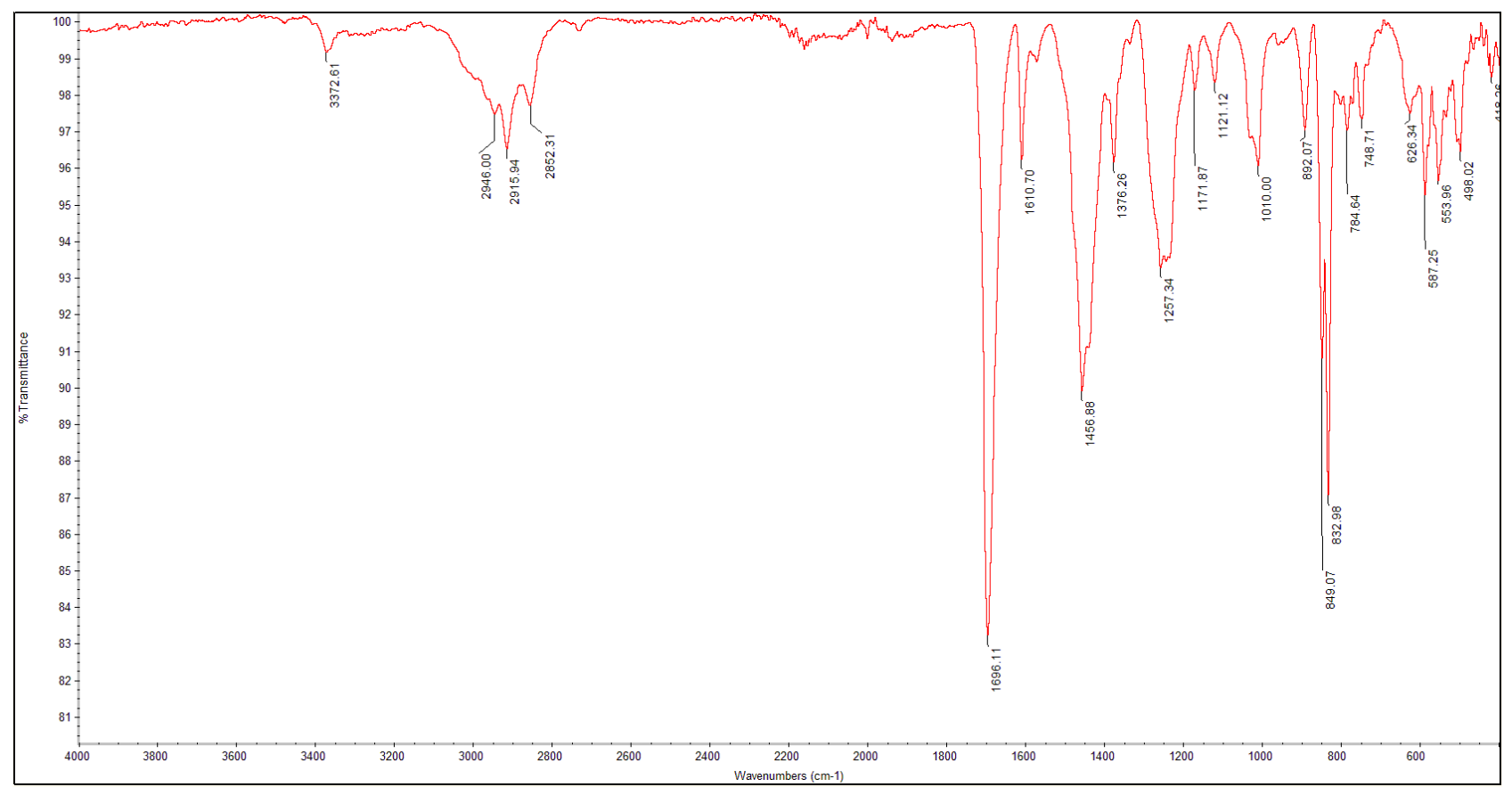

Figure S1.4. ATR-IR spectrum $\left(20^{\circ} \mathrm{C}\right)$ of $1,4-\left(\mathrm{HC}(\mathrm{O}) \mathrm{N}(\mathrm{H}) \mathrm{Ar}^{\mathrm{Mes} 2}\right)_{2} \mathrm{C}_{6} \mathrm{H}_{4}$. 


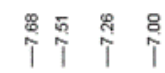

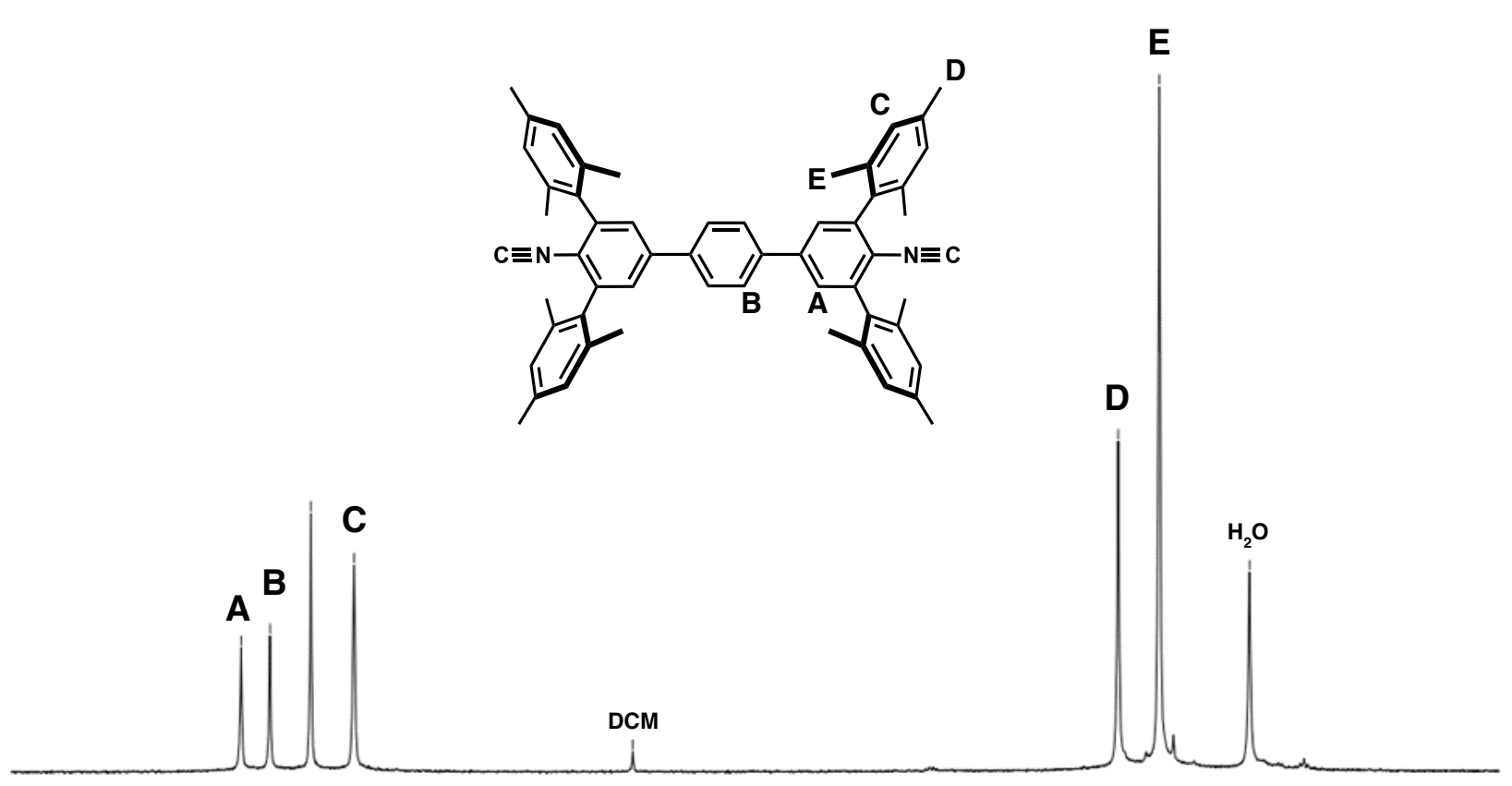

$$
9.0
$$

Figure S1.5. ${ }^{1} \mathrm{H}$ NMR spectrum $\left(\mathrm{CDCl}_{3}, 300 \mathrm{MHz}, 20{ }^{\circ} \mathrm{C}\right)$ of $1,4-\left(\mathrm{CNAr}^{\mathrm{Mes} 2}\right)_{2} \mathrm{C}_{6} \mathrm{H}_{4}$.

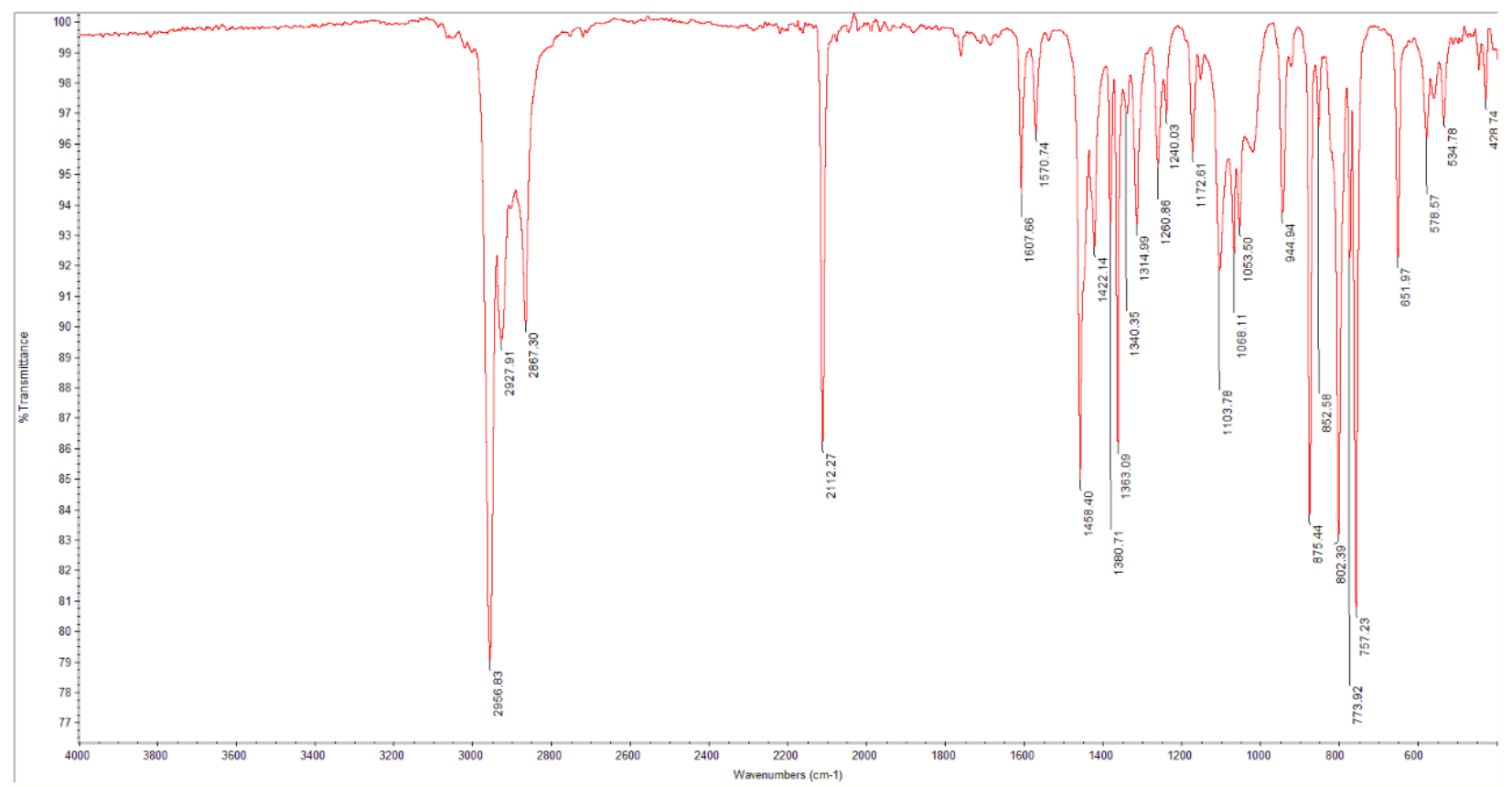

Figure S1.6. ATR-IR spectrum $\left(20^{\circ} \mathrm{C}\right)$ of $1,4-\left(\mathrm{CNAr}{ }^{\mathrm{Mes} 2}\right)_{2} \mathrm{C}_{6} \mathrm{H}_{4}$. 
S2. ATR-IR Spectroscopic Data for THF- and Pyridine-Coordinated Cu${ }^{\text {ISO }} \mathrm{CN}-4$

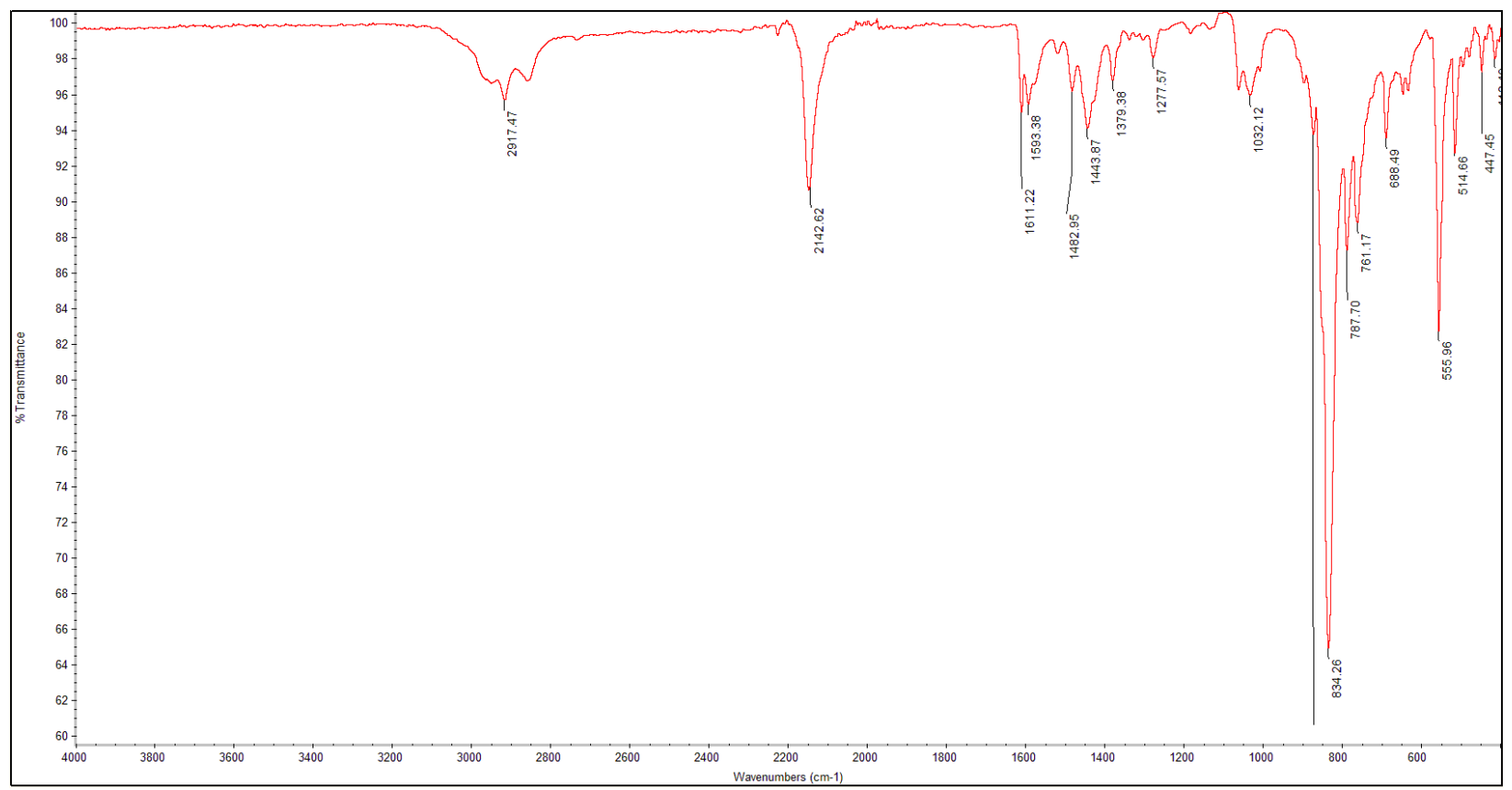

Figure S2.1. ATR-IR spectrum $\left(20^{\circ} \mathrm{C}\right)$ of "as-prepared" $\mathrm{THF}$-coordinated $\mathrm{Cu}^{\mathrm{ISO}} \mathrm{CN}-4$.

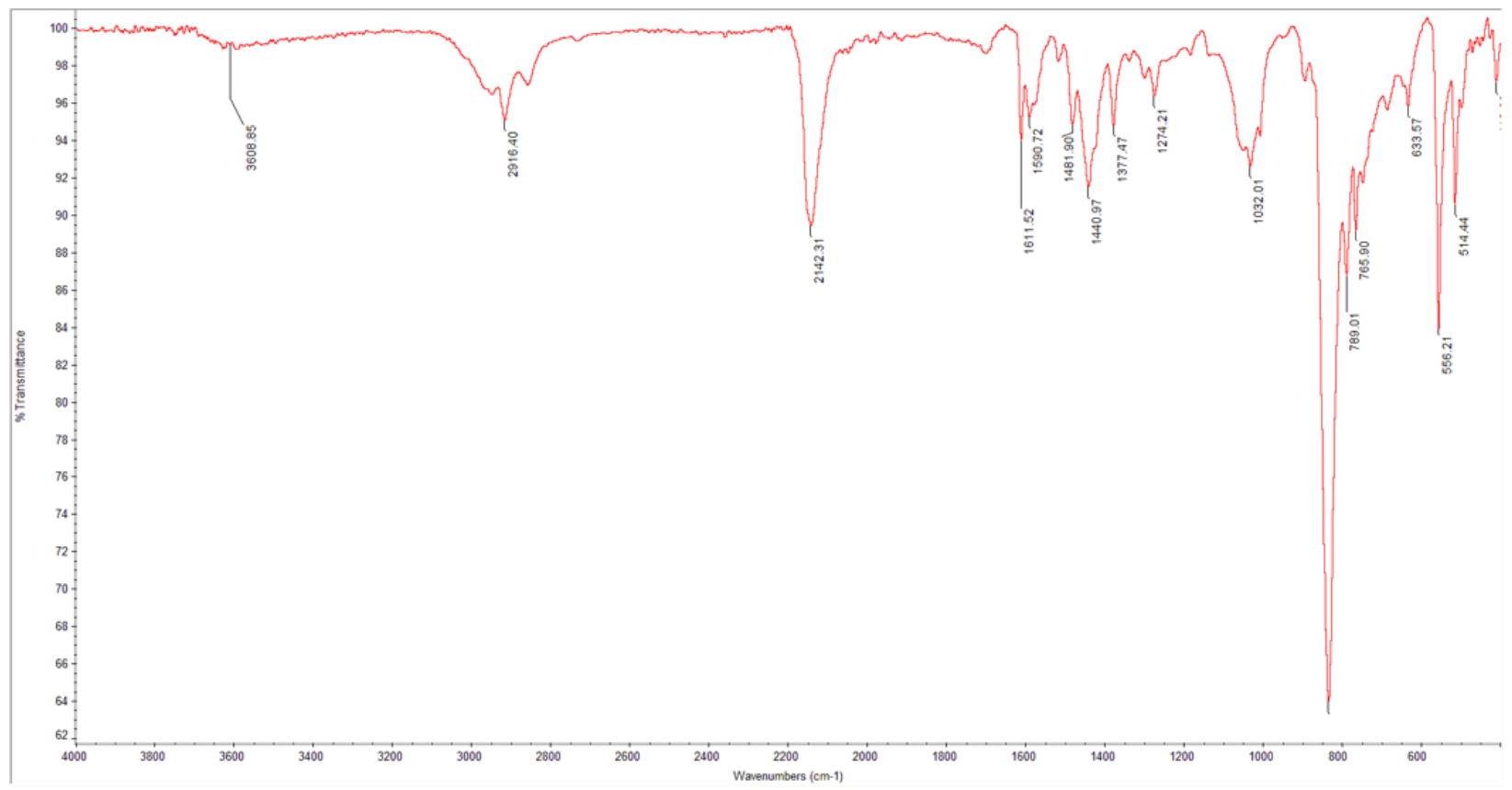

Figure S2.2. ATR-IR spectrum $\left(20{ }^{\circ} \mathrm{C}\right)$ of THF-coordinated $\mathrm{Cu}^{\mathrm{ISO}} \mathrm{CN}-4$ after exposure to deionized $\mathrm{H}_{2} \mathrm{O}$ for $5 \mathrm{~d}(120 \mathrm{~h})$. Note: the low-intensity $v_{\mathrm{OH}}$ band centered at $3609 \mathrm{~cm}^{-1}$ is likely derived from residual surface $\mathrm{H}_{2} \mathrm{O}$. 


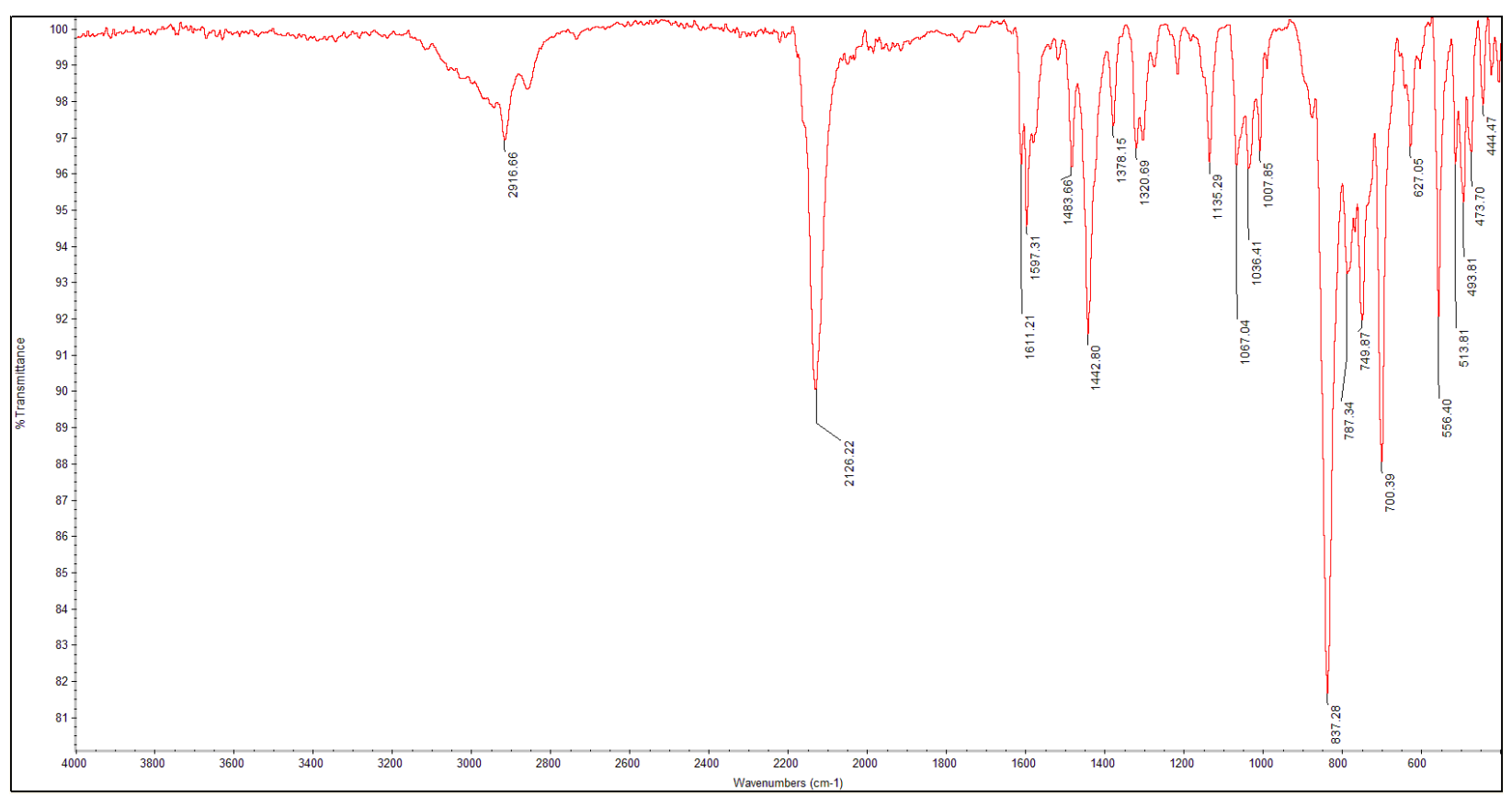

Figure S2.3. ATR-IR spectrum $\left(20{ }^{\circ} \mathrm{C}\right)$ of pyridine-coordinated $\mathrm{Cu}_{-}{ }^{\mathrm{ISO}} \mathrm{CN}-4$, obtained from treatment of THF-coordinated $\mathrm{Cu}_{-}{ }^{\mathrm{ISO}} \mathrm{CN}-4$ with 5.0 equiv pyridine in $\mathrm{THF}(12 \mathrm{~h})$.

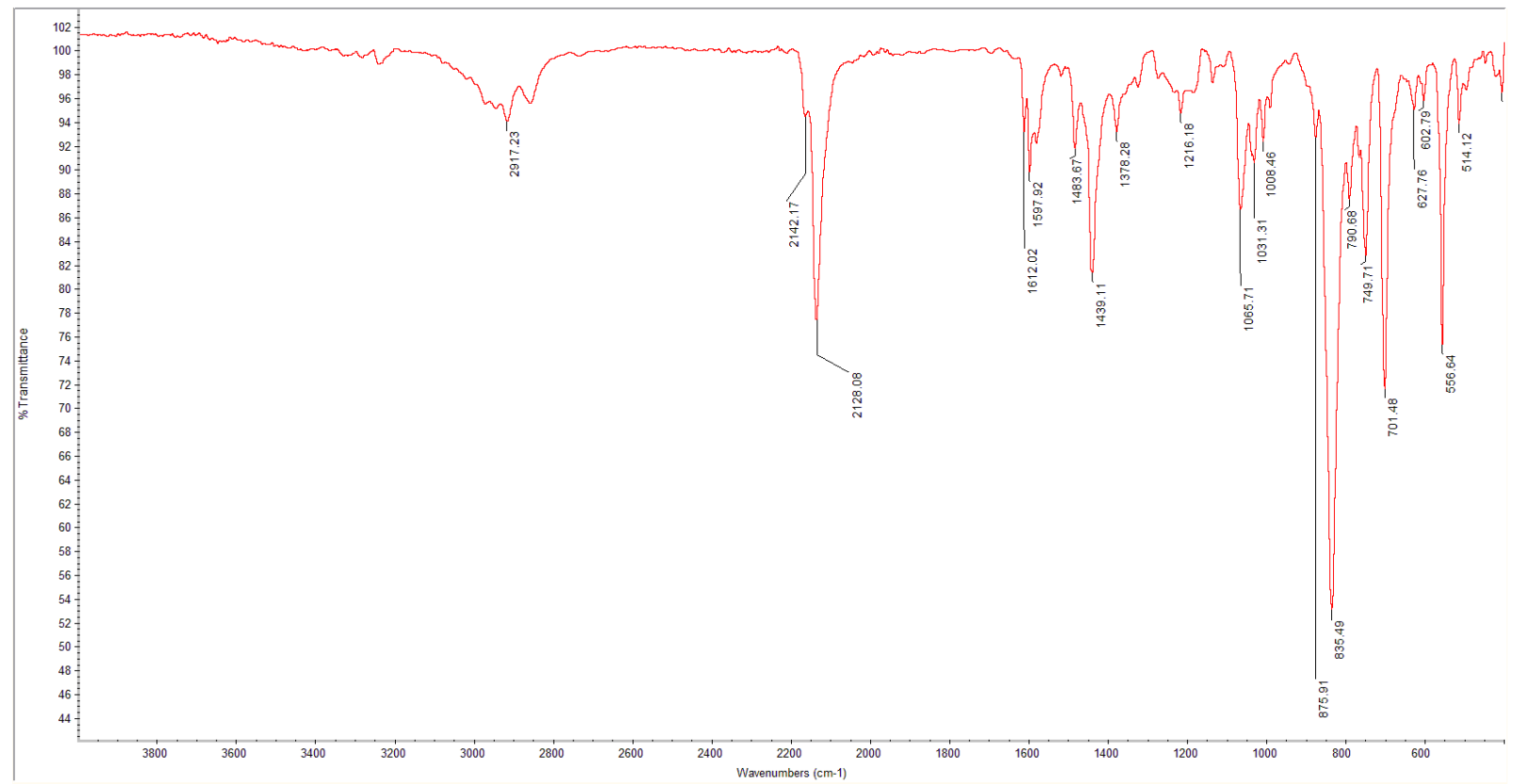

Figure S2.4. ATR-IR spectrum $\left(20{ }^{\circ} \mathrm{C}\right)$ of pyridine-coordinated $\mathrm{Cu}_{-}{ }^{\mathrm{ISO}} \mathrm{CN}-4$, obtained from treatment of THF-coordinated $\mathrm{Cu}_{-}{ }^{\mathrm{ISO}} \mathrm{CN}-4$ with 5.0 equiv pyridine in $\mathrm{H}_{2} \mathrm{O}(24 \mathrm{~h})$. Based on the relative intensity of the $2142 \mathrm{~cm}^{-1}$ band, an $85 \%$ substitution efficiency is estimated. 


\section{S3. Details of X-ray Single-Crystal and Powder Diffraction Studies}

S3.1. General. Single X-ray structure determinations were performed at $100 \mathrm{~K}$ on Bruker Platform Diffractometers equipped with $\mathrm{Mo}-\mathrm{K}_{\alpha}$ or $\mathrm{Cu}-\mathrm{K}_{\alpha}$ radiation source and an APEX-II CCD area detector. All structures were solved via direct methods with SHELXS ${ }^{1}$ and refined by full-matrix least-squares procedures using SHELXL within the Olex2 software package. ${ }^{2}$ Crystallographic data collection and refinement information are listed in Table S3.1. For both THF- and pyridine coordinated $\mathrm{Cu}_{-}{ }^{\mathrm{ISO}} \mathrm{CN}-4$, disordered and non-stoichiometric THF solvent molecules of cocrystallization are present within the solvent-accessible channels. The Platon routine SQUEEZE ${ }^{3}$ was used to account for the electron density of this disordered solvent as a diffuse contribution to the overall scattering without specific atom positions.

Powder X-ray diffraction studies on $\mathrm{Cu}_{-}{ }^{\mathrm{ISO}} \mathrm{CN}-4$ were performed at room temperature on a Bruker D8 Advanced LynxEye CCD diffractometer, equipped with $\mathrm{Cu} \mathrm{K}_{\alpha}$ radiation $(\lambda=1.54178 \AA)$ and $\mathrm{K}_{\beta}$ filter. Diffraction measurements were set to $40 \mathrm{~V}$ and $40 \mathrm{~mA}$.

\section{S3.2. Specifics of Structure Solutions.}

$\mathrm{Cu}^{\mathrm{ISO}} \mathbf{C N}-4$. The $\left[\mathrm{PF}_{6}\right]^{-}$counteranion is positionally disordered and was modeled and refined anisotropically. Two carbon atoms present on the para-phenyl linker is positionally disordered and was modeled by parts and refined anisotropically. One carbon atom on the coordinated THF is positionally disordered and was modeled by parts and refined anisotropically. Significant disorder was observed for 6.5 THF solvent molecules of cocrystallization for the asymmetric unit cell. These were treated with SQUEEZE and their electron density removed prior to refinement.

$\mathrm{Cu}^{\text {ISO }} \mathbf{C N}$-py. Para-phenyl linker present on one isocyanide ligand is positionally disordered and was modeled by parts and refined anisotropically. Significant disorder was observed for $5.5 \mathrm{THF}$ solvent molecules of co-crystallization for the asymmetric unit cell. These were treated with SQUEEZE and their electron density removed prior to refinement.

S3.2. CCDC Deposition. All crystal structures have been deposited with the Cambridge Crystallographic Data Center (CCDC) and have been assigned the following CCDC deposition numbers:

- 1,4-(CNAr $\left.{ }^{\mathrm{Mes} 2}\right)_{2} \mathrm{C}_{6} \mathrm{H}_{4}: 2005977$

- $\mathrm{Cu}^{\mathrm{ISO}} \mathrm{CN}-4-\mathrm{THF}: 2005978$

- $\mathrm{Cu}_{-}{ }^{\mathrm{ISO}} \mathrm{CN}-4-\mathrm{py}: 2005979$ 


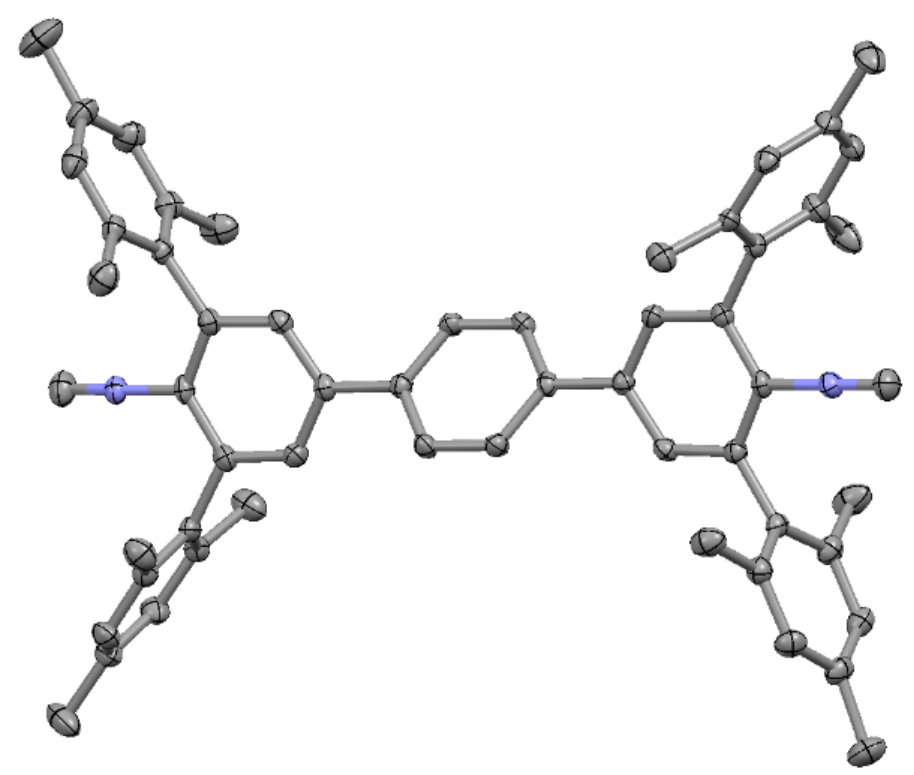

Figure S3.1. Molecular structure of 1,4- $\left(\mathrm{CNAr}^{\mathrm{Mes} 2}\right)_{2} \mathrm{C}_{6} \mathrm{H}_{4}$.

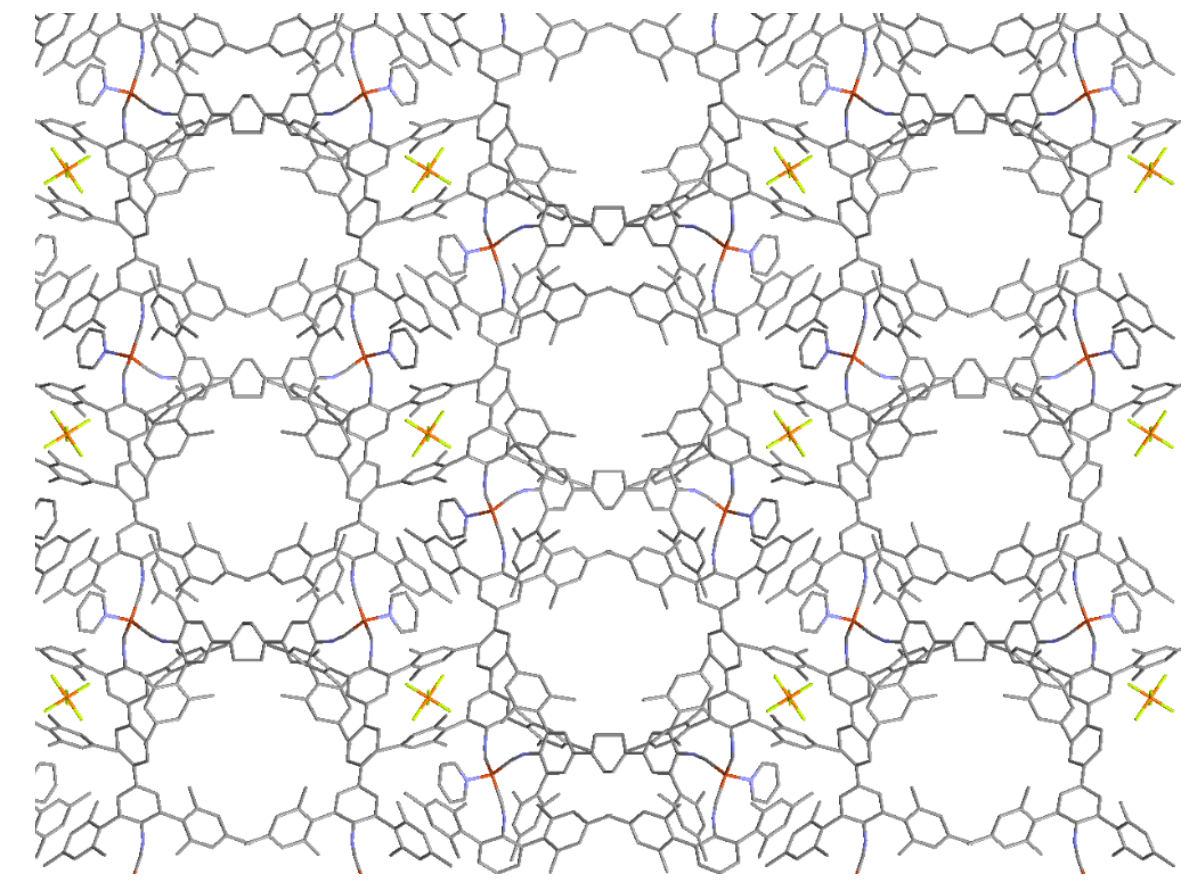

Figure S3.2 Single-crystal X-ray structure of $\mathrm{Cu}^{\mathrm{ISO}} \mathrm{CN}$-py with view of the channel structure down the crystallographic $b$-axis. 


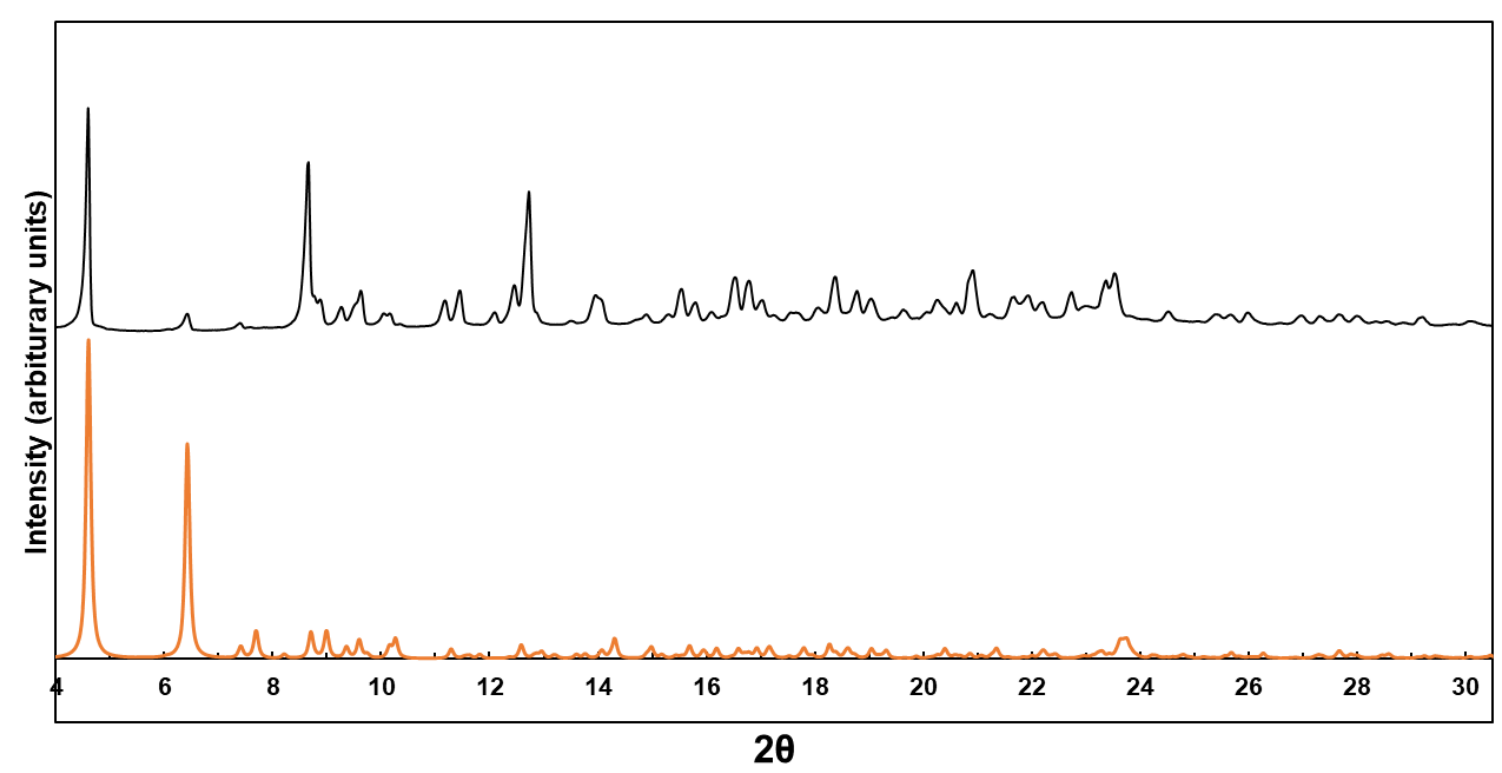

Figure S3.3. PXRD pattern of $\mathrm{Cu}^{\mathrm{ISO}} \mathrm{CN}-4$, experimental (black) and simulated from single crystal diffraction (orange).

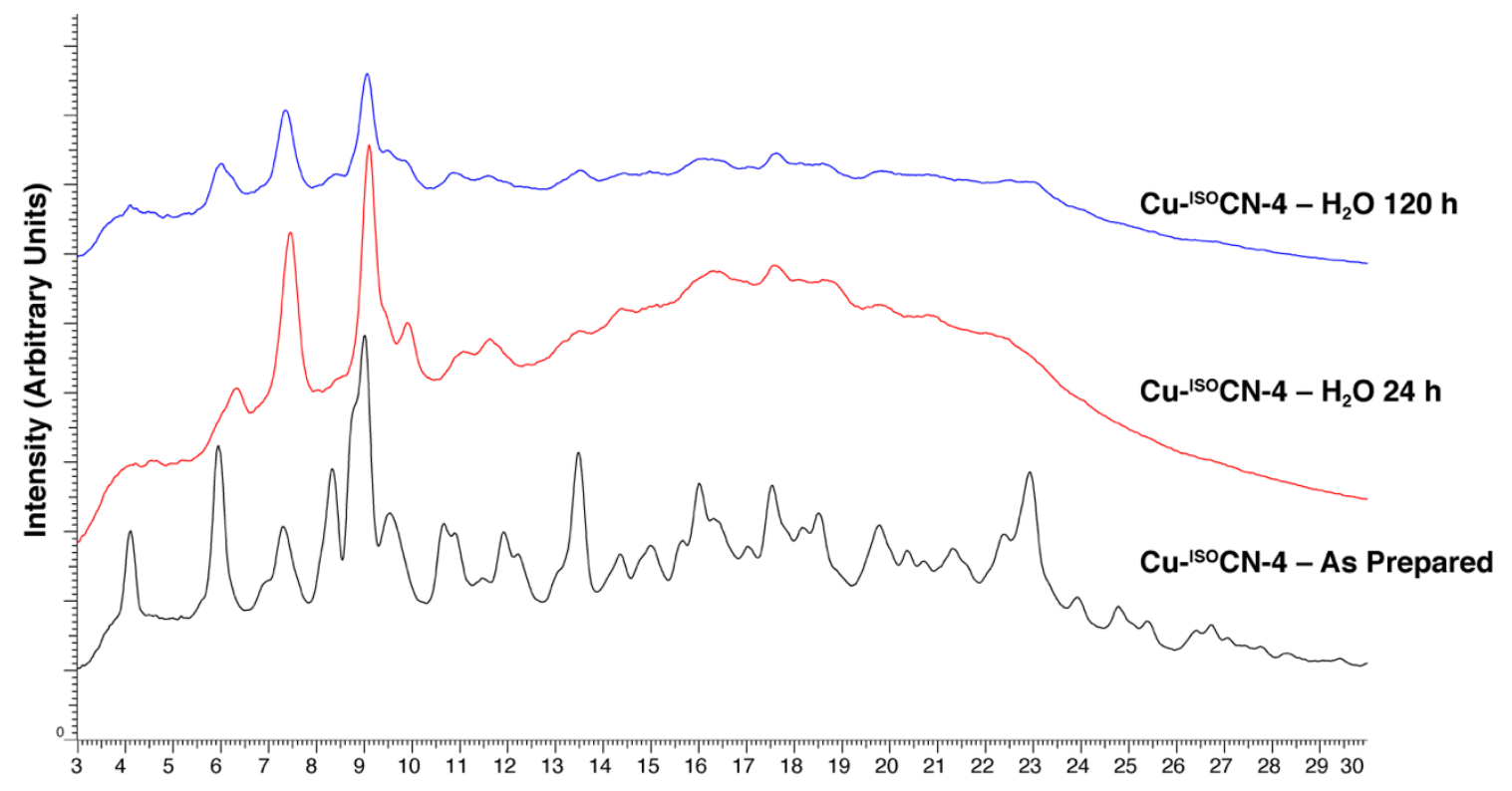

Figure S3.4. PXRD patterns of "as-prepared" $\mathrm{Cu}^{\mathrm{ISO}} \mathrm{CN}-4$ (bottom) and after exposure to deionized water for $24 \mathrm{~h}$ (middle) and $120 \mathrm{~h}$ (top), respectively. A loss in crystallinity is observed as a function of exposure time. 


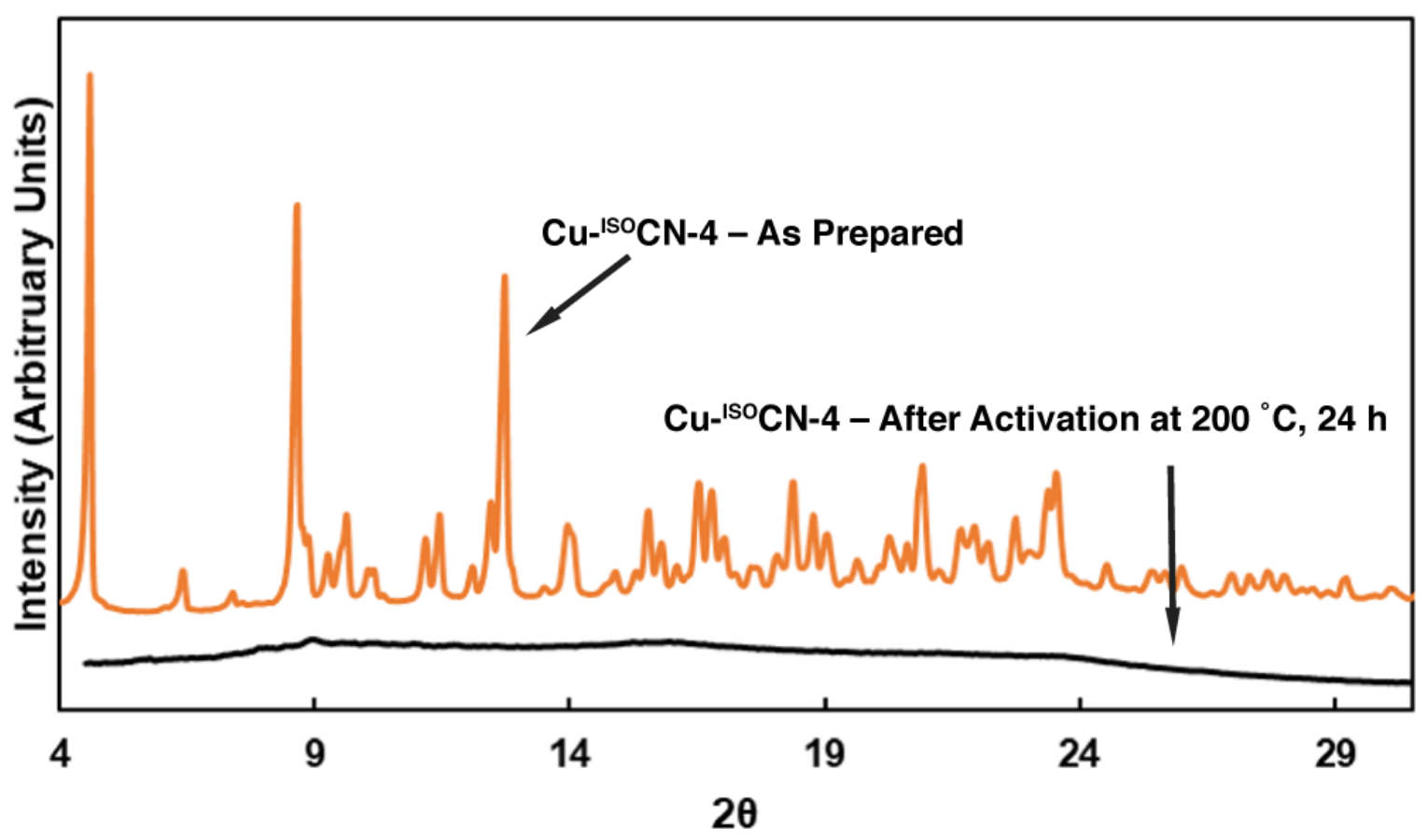

Figure S3.5. PXRD pattern of "as-prepared" $\mathrm{Cu}^{\mathrm{ISO}} \mathrm{CN}-4$ (orange) and after activation at $200{ }^{\circ} \mathrm{C}$ for $24 \mathrm{~h}$ (black). After activation, complete framework collapse and loss of crystallinity is indicated.

Table S3.1. Crystallographic Data Collection and Refinement Information

\begin{tabular}{cccc}
\hline Name & $1,4-\left(\mathrm{CNAr}{ }^{\mathrm{Mes} 2}\right)_{2} \mathrm{C}_{6} \mathrm{H}_{4}$ & $\mathrm{Cu}^{\text {ISO }} \mathrm{CN}-4-\mathrm{THF}$ & $\mathrm{Cu}^{\mathrm{ISO}} \mathrm{CN}-\mathrm{py}$ \\
Formula & $\mathrm{C}_{56} \mathrm{H}_{54} \mathrm{~N}_{2}$ & $\mathrm{C}_{176} \mathrm{H}_{172} \mathrm{Cu}_{2} \mathrm{~F}_{6} \mathrm{~N}_{6} \mathrm{O}_{2} \mathrm{P}$ & $\mathrm{C}_{178} \mathrm{H}_{166} \mathrm{Cu}_{2} \mathrm{~F}_{6} \mathrm{~N}_{8} \mathrm{P}$ \\
Crystal System & Monoclinic & Orthorhombic & Orthorhombic \\
Space Group & $P{ }_{1} / n$ & $P c c n$ & $P c c n$ \\
$a, \AA$ & $15.7545(15)$ & $43.0814(5)$ & $43.5731(7)$ \\
$b, \AA$ & $19.9193(13)$ & $12.8155(2)$ & $12.7500(2)$ \\
$c, \AA$ & $16.1735(11)$ & $31.7705(4)$ & $31.8860(6)$ \\
$\alpha$, deg & 90 & 90 & 90 \\
$\beta$, deg & $115.950(3)$ & 90 & 90 \\
$\gamma$, deg & 90 & 90 & $17714.5(5)$ \\
$\mathrm{V}, \AA^{3}$ & $4563.8(6)$ & $17540.8(4)$ & 4 \\
$Z$ & 4 & 4 & $\mathrm{Cu}-\mathrm{K \alpha}, 1.54178$
\end{tabular}




$\begin{array}{cccc}\rho \text { (calcd. }), \mathrm{g} / \mathrm{cm}^{3} & 1.099 & 1.013 & 1.008 \\ \mu(\text { Mo Ka }), \mathrm{mm}^{-1} & 0.063 & 0.807 & 0.797 \\ \text { Temp, } \mathrm{K} & 100 & 100 & 100 \\ \theta \text { max, deg } & 25.694 & 68.280 & 50.602 \\ \text { data/parameters } & 8660 / 535 & 16031 / 899 & 9344 / 904 \\ R_{I} & 0.0478 & 0.0645 & 0.0587 \\ w R_{2} & 0.1244 & 0.1689 & 0.1587 \\ \text { GOF } & 1.021 & 1.028 & 1.016\end{array}$

\section{S4. Contact Angle Measurements, TGA/DSC and Gas Sorption Analyses.}

S4.1. Thermal Analysis. Thermogravimetric analysis was performed on $\sim 5-15 \mathrm{mg}$ of material that had been dried under dynamic vacuum. Analysis was conducted under a stream of dry dinitrogen gas $(80 \mathrm{~mL} / \mathrm{min})$ using a Mettler Toledo TGA/DSC 1 STARe System running from 30 ${ }^{\circ} \mathrm{C}$ to $800{ }^{\circ} \mathrm{C}$ with a ramping rate of $5{ }^{\circ} \mathrm{C} / \mathrm{min}$.

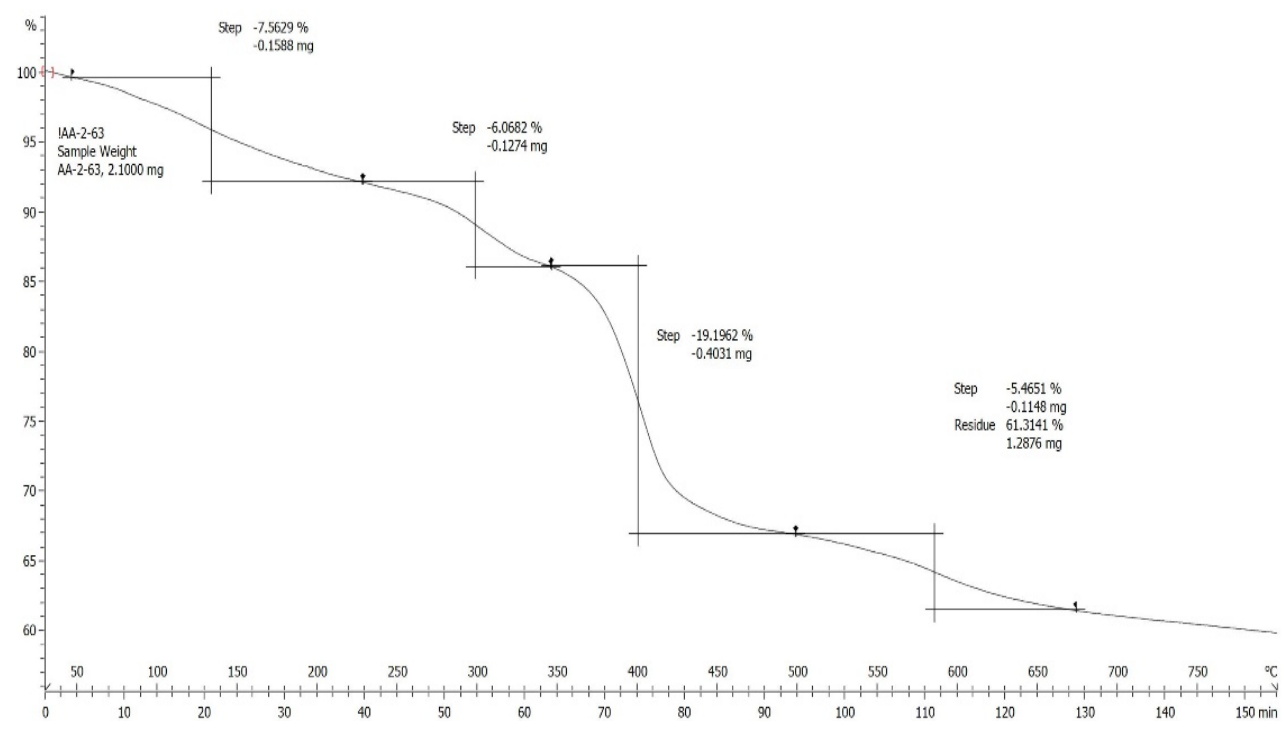

Figure S4.1. Thermogravimetric analysis of $\mathrm{Cu}^{\mathrm{ISO}} \mathrm{CN}-4$.

S4.2. Surface Area Analysis. Samples were prepared on and measured using a Micrometrics ASAP 2020 Adsorption Analyzer. Approximately $33 \mathrm{mg}$ of material was transferred to a preweighed sample tube and degassed at $200{ }^{\circ} \mathrm{C}$ for at least 24 hours or until the outgas rate was below $5 \mathrm{mmHg}$. The sample tube was reweighed to obtain a mass for the sample. Measurements were collected on three independent samples at $77 \mathrm{~K}$ employing $\mathrm{N}_{2}$ of $99.999 \%$ purity using the volumetric technique. Analyses performed on $\mathrm{Cu}^{\mathrm{ISO}} \mathrm{CN}-4$ degassed at $105{ }^{\circ} \mathrm{C}$ revealed insignificant surface areas. 


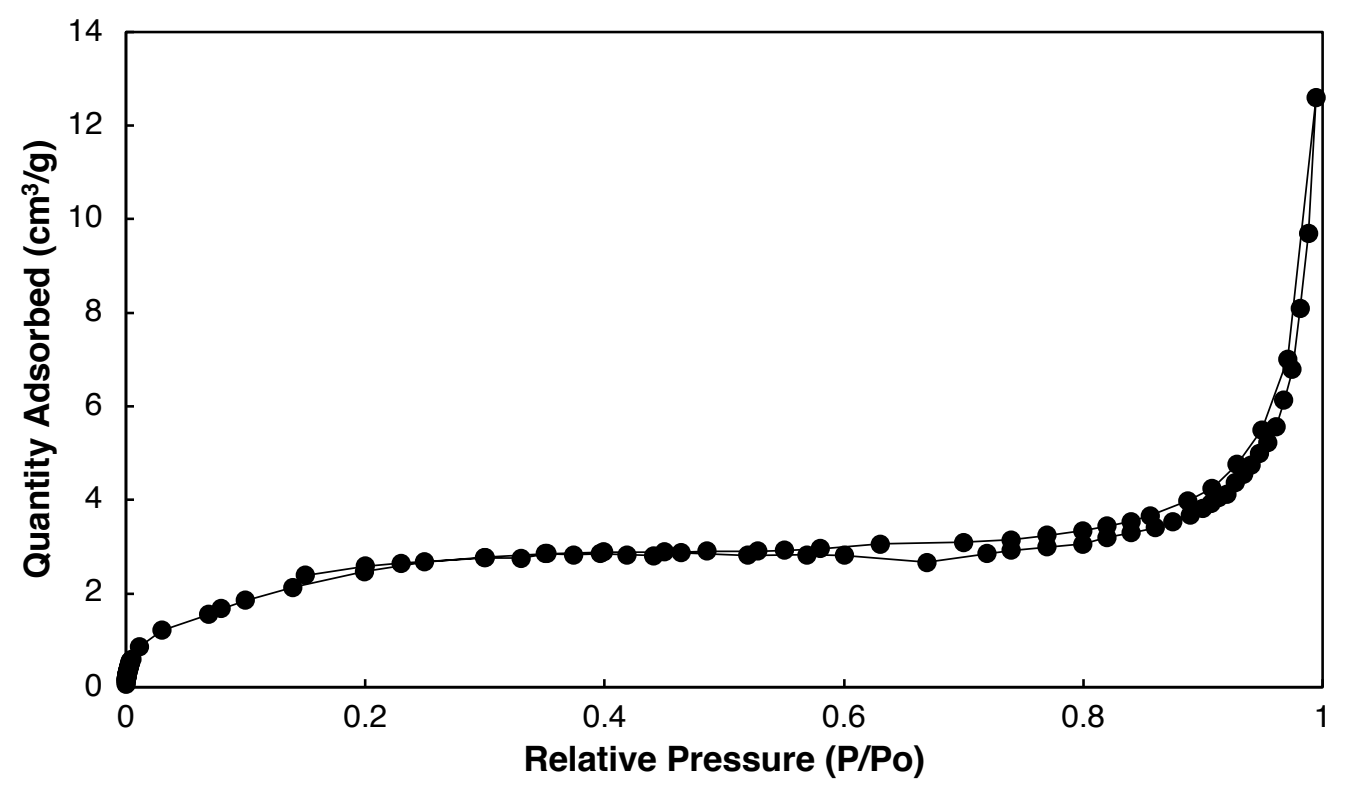

Figure S4.2. $\mathrm{N}_{2}$ sorption isotherm analysis at $77 \mathrm{~K}$ of $\mathrm{Cu}^{\mathrm{ISO}} \mathrm{CN}-4$ after activation at $200{ }^{\circ} \mathrm{C}$.

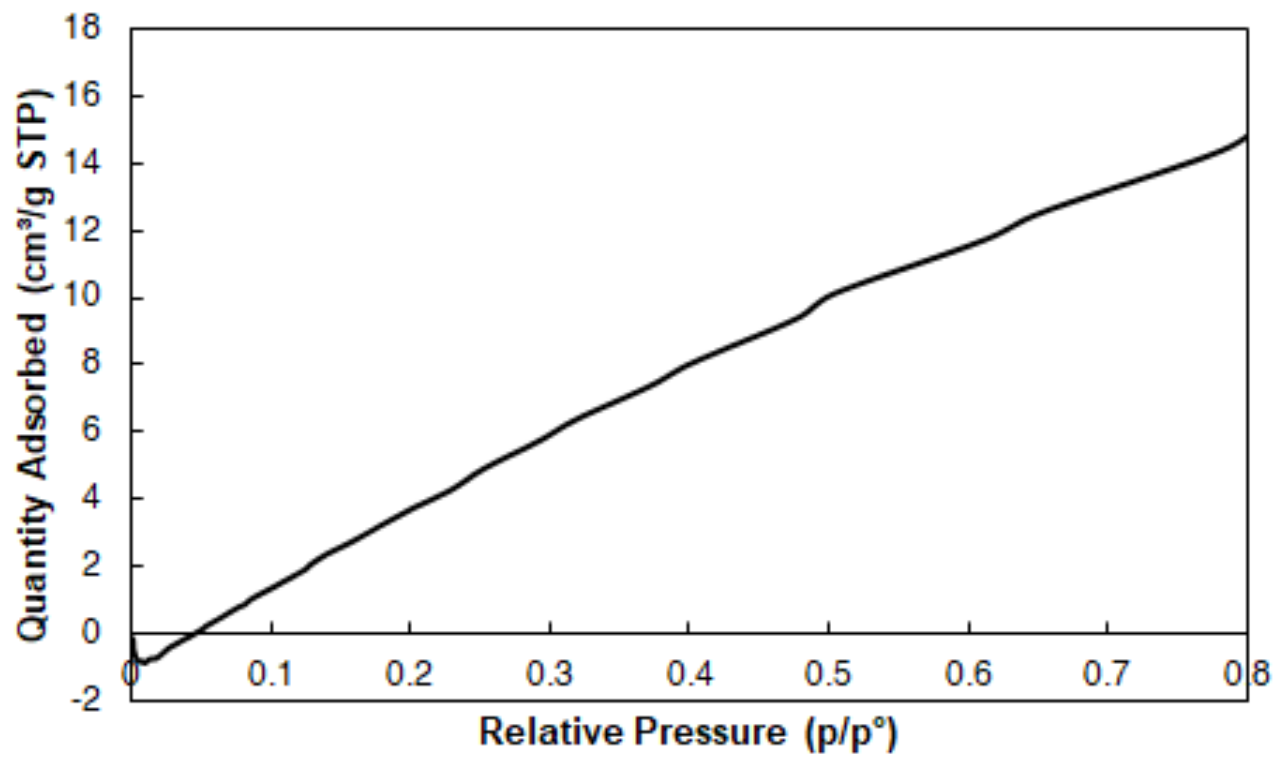

Figure S4.3. $\mathrm{CO}_{2}$ sorption isotherm analysis at room temperature of $\mathrm{Cu}^{\mathrm{ISO}} \mathrm{CN}-4$ after activation at $200{ }^{\circ} \mathrm{C}$. 
S4.3. Contact Angle Measurements on $\mathrm{Cu}^{\mathrm{ISO}} \mathrm{CN}-4$. Contact angle measurements were recorded using a Tantec CAM-micro Contact Angle Meter. Samples of $\mathrm{Cu}^{\mathrm{ISO}} \mathrm{CN}-4$ were prepared as described in Section S1.8 and dried under dynamic vacuum prior to analysis. Samples were then pressed onto a glass slide using a spatula. A drop of water (tested to 18.2 MW) was slowly dropped from a microsyringe and the contact angle measured.

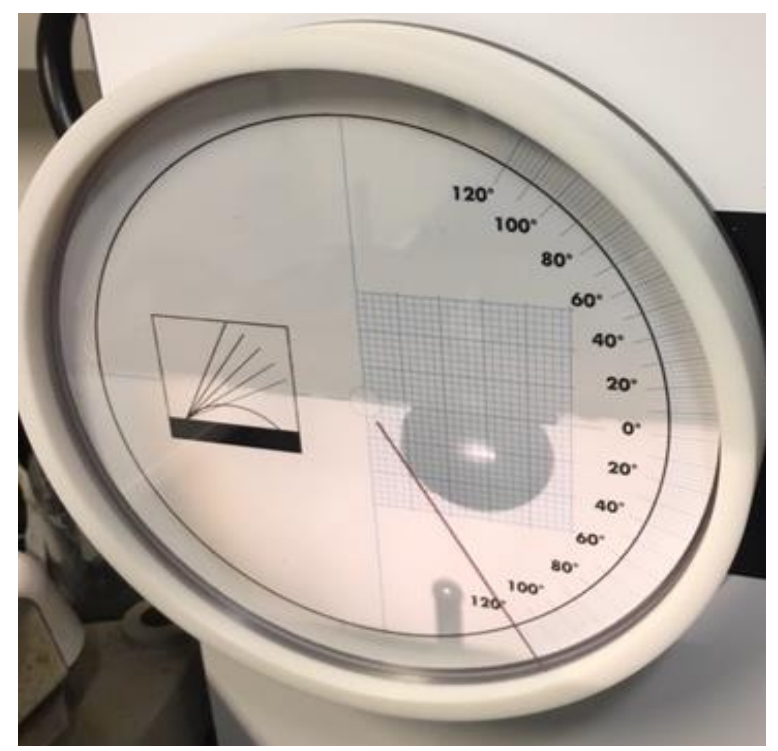

Figure S4.4. A representative image of the contact angle meter upon addition of a drop of $\mathrm{H}_{2} \mathrm{O}$ to $\mathrm{Cu}^{\mathrm{ISO}} \mathrm{CN}-4$.

\section{S5. References}

1. Sheldrick, G. A short history of SHELX. Acta Crystallogr. A 2008, 64,112-122.

2. Dolomanov, O. V.; Bourhis, L. J.; Gildea, R. J.; Howard, J. A. K.; Puschmann, H. OLEX2: a complete structure solution, refinement and analysis program. J. Appl. Crystallogr. 2009, 42, 339-341.

3. Van Der Sluis, P.; Spek, A. L. BYPASS: an effective method for the refinement of crystal structures containing disordered solvent regions. Acta Crystallogr. A 1990, 46, 194-201. 